\title{
Innovative trends of further education in the tourism and hospitality industry
}

\author{
Lyudmila Kazmina ${ }^{1, *}$, Valeria Provotorina ${ }^{1}$, Vadim Makarenko ${ }^{1}$, and Antonina Petrenko ${ }^{1}$ \\ ${ }^{1}$ Don State Technical University, 344003, Gagarina Sq., 1, Rostov-on-Don, Russia
}

\begin{abstract}
The study is directed toward the analysis of innovative trends in further education in the tourism and hospitality industry. The article gives proof to relevance and feasibility of optimizing further vocational education in accordance with social and economic needs of the country, needs of an individual, society and the state.
\end{abstract}

\section{Introduction}

At the present stage of development of society in the context of modernization of the education system, as well as of social, political, economic reforms, changes in the tourism and hospitality industry, the demand for specialists in this area, as well as for educational services, has increased. In this regard, relevance of studying both innovative processes and patterns of their behavior, and the need for their implementation in further vocational education in order to increase effectiveness of training of highly qualified personnel in the tourism and hospitality industry, is obvious.

The country's education system is greatly influenced by both socio-economic and political conditions. The education policy in modern Russia has recently been subject to significant changes associated with fundamental changes in the life of society. Russian education has been placed before tasks of modernizing the education sector, creating a mechanism for sustainable development of the education system in accordance with social and economic needs of the country, needs of an individual, society and the state. Occurring transformations result in changes in functioning of educational institutions of higher education. Universities are faced with tasks related not only to solving problems of ensuring their viability, finding financial sources of sustainable development, but also to issues of significant enhancement of quality and efficiency of education. In terms of fulfillment of these tasks, various structures of further vocational education, the mission and scope of activity of which should change significantly in the context of the idea of continuous education become more important. Reorientation of the educational strategy towards lifelong education makes it necessary to optimize further vocational education in both organizational and research context.

Upgrade of personnel qualifications is one of the main factors of effective operating of enterprises in the hospitality industry against the backdrop of the fast developing service sector, changing customer needs for service types and quality. Knowledge and skills of personnel of hotel and tourism enterprises become dated and irrelevant sooner or later.

\footnotetext{
* Corresponding author: kafedra_tiig@mail.ru
} 
Therefore, workers of such a dynamic sphere as tourism and hotel industry should constantly upgrade their skills and go into further vocational education.

The purpose of the present paper is to analyze the specifics of innovations in the field of further vocational education and to identify trends in their development in the tourism and hospitality industry.

Since the defining characteristic of our times is energizing of innovative processes in further vocational education, it is necessary to change the educational system - a different content of education, alternative approaches, and relationships. At the same time, it is essential to summarize the experience of both foreign and domestic specialists in the field of further education in the sphere of the tourism and hospitality industry.

\section{Background and methods}

According to the Russian legislation, education is a single purposeful process of upbringing and training, which is an important benefit and is implemented to serve the interests of a person, family, society and the state, as well as a set of acquired knowledge, skills, attitudes, experience and competence of a certain volume and complexity for the purposes of intellectual, spiritual and moral, creative, physical and /or professional development of a person, and to meet his or her educational needs and interests. In present-day conditions of reformation of the Russian educational system, various innovative processes get more widespread. The sphere of education is one of the most leading industries, largely determining creation of innovative climate and competitiveness of the economy as a whole. Approbation and implementation of innovations in the education system should be considered as a continuous process, as a component of everyday educational activities.

In the early twentieth century, a new field of knowledge was formed - the science of the new, innovations, which studied the laws of emergence, development and implementation of innovations in material production. However, in a short time, innovations stepped into the social sphere, and, consequently, into education, in which the foundations of pedagogical innovation are laid.

Research methods of innovations in education are studied by such foreign authors as: A. Mai Walder, 2017[1], J.Chun-Chung Chow, Cheng Ren, Brenda Mathias, Jiaying Liu 2019 [2], Meiju Keinänen, Jani Ursin, Kari Nissinen 2018 [3], Viv Ellis, Ann Childs 2019 [4], Nicole C.Jackson 2019[5]. In the domestic science, the problems of innovation in higher education are dealt with by such authors as: S.Sh. Kazdanyan 2016 [6], Z. Sh. Akbarova 2011 [7], I.K Voytovich 2014 [8], N. Nagibina, N. Ippolitova 2012 [9] and others. The most complete definition of innovations in further education is considered as interpretation of this term as relevant and significant innovations in pedagogical reality, which lead to a previously unknown result, develop the theory and practice of teaching, arising from a variety of initiatives and innovations that become promising for evolution of further education and have a positive effect on its development.

When identifying the specifics of innovativeness of further education in the field of tourism and hospitality industry, on the one hand, it was necessary to analyze the papers related to education in tourism of such foreign authors as: Jianwei Qian, Rob Law, Xinjian Li 2019 [10], Hyun Jeong Kim, Miyoung Jeong 2018 [11], Ana Dias Daniel, Rui Augusto Costa, Mariana Pita, Carlos Costa 2017 [12], Valentina Ndou Gioconda, Mele Pasquale, Del Vecchio 2019 [13], Jude Walker, Vimbiso Ngara Manyamba 2020[14], Carl Behnke, Soobin Seo, Kay Miller 2014[15], Yaniv Belhassen, Kellee Caton 2011 [16], Cathy H.C.Hsu 2018 [17], M. Joppe, S. Elliot 2015 [18]. On the other hand, the authors stuied the features of innovations in the tourism and hospitality industries, reflected in the following papers: Dorthe Eide, Lars Fuglsang, Jon Sundbo 2017 [19], S.Divisekera, V.K. Nguyen 2018 [20], Beatriz Casais, Juliana Fernandes, Mariana Sarmento 2020 [21], Birgit 
Pikkemaat, Mike Peters, Bernhard Fabian Bichler 2019 [22], L.N. Kazmina, V.V. Provotorina 2015,2016 [23,24], L.N. Kazmina, V.S. Makarenko, V.V. Provotorina, T.N. Grigorenko [25].

Among the major methodological approaches applied to the study of further vocational education, it is necessary to give accent to the systemic, institutional and integrated approaches. They make it possible to study trends and processes taking place in further education. In the course of the study, the authors applied a typological approach that permits to define not only the current trends, problems and contradictions in transformation of further education, but also to identify possible prospects for this process. Scientific provisions, conclusions and recommendations contained in the article are based on the use of combined methods of historical and logical analysis.

\section{Results and discussion}

Consumers of tourist services (tourists) become more demanding of the qualifications of service personnel every day. The Russian tourism industry has undergone dramatic changes in recent years:

- wide diversification and increase of demand for highly qualified personnel of the tourism profile, caused by objectively established global trends in development of the tourism industry;

- changing the consumer's views toward the range and quality of tourist services;

- active development and widespread occurrence of new teaching technologies in tourism education, based on the synthesis of advanced theory and practice of the best Russian and foreign educational institutions.

The most important element in development of the tourism sector, high-quality organization of tourist and recreational space, in attracting and retaining the tourist flow are qualified personnel in the tourism sector.

Despite the serious fundamental base of general theoretical knowledge, the professional, practical level of graduates does not fully meets requirements of the field. There are problems in specialization, real-life experience, knowledge of modern technologies, insufficient foreign language competence, as well as a gap between curricula for personnel training for the industry and its real needs.

According to the Federal Law "On Education in the Russian Federation", further education is oriented to formation and development of creativity, satisfaction of individual needs for intellectual, moral and physical enhancement, formation of the culture of healthy and safe lifestyle, health promotion, as well as to management of their free time. The law states that supplementary education programs are subdivided into programs for general development implemented for both children and adults and pre-professional programs in the field of arts, physical culture and sports, implemented for children. In article 76 of the mentioned law, further vocational education is defined; it is oriented to satisfaction of educational and professional needs, assuring of compliance of qualifications of an employee with changing conditions in a particular area of activity and social environment. Further vocational education can also be defined as training of workers with primary, secondary, higher, postgraduate education in order to increase their professional knowledge and improve their business qualities or for retraining in case of changing the field of professional activity. This definition reflects the fact that one of the key conditions for obtaining further vocational education is the presence of a diploma of graduation from a secondary specialized or higher educational institution. That is why it is carried out on a paid-for basis.

Within the framework of further vocational education, two types of supplementary professional programs are implemented: proficiency enhancement programs and 
professional retraining programs. The proficiency enhancement programs program is oriented to enhancement and/or obtaining new competencies necessary for professional activity, and/or professional upgrading within the existing qualifications. The professional retraining program is oriented to obtaining the competence necessary to perform a new type of professional activity, acquiring a new qualification.

The content of the supplementary professional program is defined by the educational program developed and approved by the organization carrying out educational activities. Scope of supplementary professional programs is sensitive to professional standards, qualification requirements specified in qualification guides for relevant positions, professions and specialties, or qualification requirements for professional knowledge and skills necessary for performance of official duties. The supplementary professional program can be implemented in the form of job training carried out in order to study best practices, consolidate theoretical knowledge gained during in the course of studying up programs of professional retraining or proficiency enhancement programs, and acquiring practical skills and abilities in order to effectively apply them in the performance of their duties. Job training can be both be individual and group and includes such activities as:

- independent work with educational publications;

- acquisition of professional and organizational skills;

- study of organization and practices of job;

- direct involvement in the organization's job scheduling;

- work with technical, regulatory and other documentation;

- performance of functional duties of officials (as an interim);

- participation in meetings, business meetings.

Training in supplementary professional programs is carried out both at a time and continuously, and in stages (discretely), including through studying up individual subjects, courses, disciplines (modules), practical training, application of network forms, in the manner prescribed by the educational program and/or by an agreement on education. Studying up of supplementary vocational educational programs results in the final certification of students in the form independently determined by the organization carrying out educational activities. Learners who have successfully mastered the corresponding supplementary vocational program and passed final certification are issued a certificate of proficiency enhancement or a diploma of professional retraining.

Implementation of further education programs is carried out by both specialized structural units of further education, realizing only supplementary education programs, and educational structural units that realize programs of higher and further education.

At the present stage of development of the further education system, three focus areas of institutions of further vocational education can be distinguished:

1. Institutes or faculties of proficiency enhancement, which are subdivisions of universities. These subjects carry out their activities on the basis of a license issued by the university and involve full-time university teachers in implementation of further education programs.

2. Units of universities that have their own license for educational activities and are held on trust.

3. Independent educational institutions of further vocational education.

Further education at a university gives special opportunities for development of education as a whole, including for the advance renewal of its content in accordance with tasks of the country's long-term development. In fact, it is an innovative platform for refinement of educational programs, models and technologies of the future.

On the one hand, further education at a university consists in the process of education and training with the help of various supplementary educational programs and provision of additional educational services; it provides students with additional knowledge, skills, and practical skills in educational programs. These educational programs provide for additional 
study of individual disciplines and sections of disciplines necessary for professional activity. On the other hand, further education in higher educational institutions makes it possible to improve and expand qualifications of specialists, to ensure their adaptation to modern economic and social conditions, and to conducting of professional activities. In our opinion, the most effective, innovation-oriented and competitive structure that implements various types of further education programs in the tourism and hospitality industry may be a specialized university unit that combines academic staff of a university, on the one hand, and leading industry practitioners, on the other.

As it is known, a number of entrepreneurs invest heavily in organization of recreation, development of routes and excursion programs, construction of hotels, etc. But in order to provide quality services, it is necessary to have appropriate qualifications. The task of further education in the area of tourism is to train out-and-out professional. In the absence of a diploma of higher or secondary vocational education in the areas of training "tourism" or "hotel business", you can get a second education in your specialty, which will take several years, or with a diploma from any non-core university or college, study up retraining courses and acquire the desired qualifications. Innovative trends in additional education in tourism are presented in Figure 1.

Professional retraining programs under the tourist direction may be intensive and advanced. Intensive course curricula are designed for 250-500 academic hours. After completing the courses, you can get a diploma of further education in about 2.5-4 months. The volume of advanced programs is more than 500 hours, and the classes will take about six months. But practice shows that employers have more demand for documents confirming the completion of such courses. When choosing a professional retraining program ("Hotel Administration", "Tourism Manager", "Safety in Tourism", "Tour Guide", "Wellness Tourism", "Business Tourism"), it is necessary to clearly define the direction of future work, it is also important to clarify what qualifications will be recorded in the diploma. 


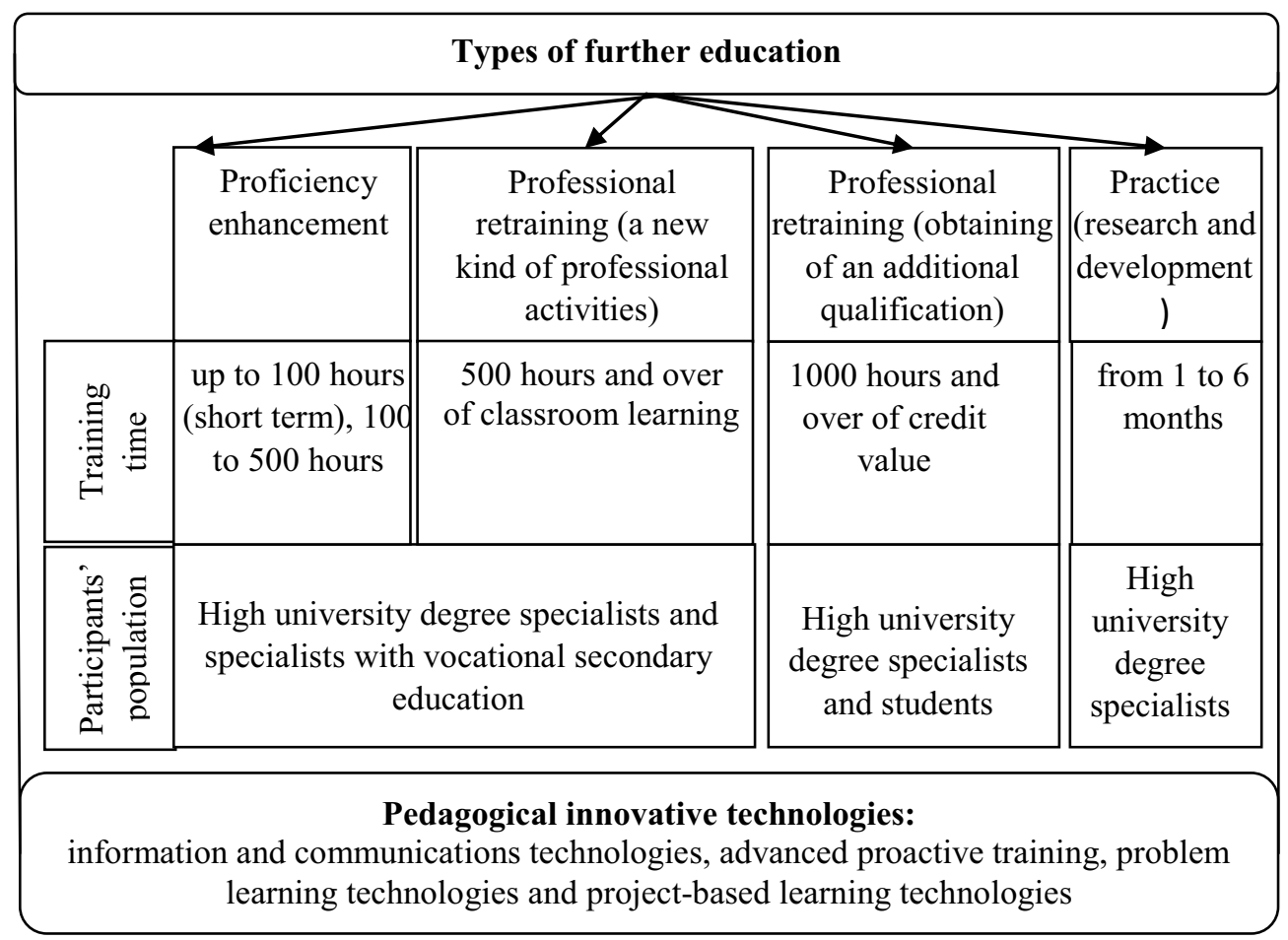

Fig. 1. Innovative trends in further education

Proficiency enhancement of workers actively working in the tourism and hospitality industry is relevant. Proficiency enhancement courses play a facilitating role in tracking of trends and staying competitive. They are especially useful when transferring from a line or managerial level to a administration, when you need to expand the boundaries of your competence; when moving to a related professional field; if it is necessary to brush up in case the experience was interrupted for several years. When choosing a proficiency enhancement program, one should focus on its content, which is reflected in the titles of topics.

The task of acquiring relevant and specific practical knowledge and skills is attached to further education and can be considered as a part of the structure of continuing learning.

Further vocational education is a promising area for development of educational activities, an important component that makes it possible to integrate different levels and forms of education in order to achieve a more flexible educational trajectory. Regardless of the form, it is oriented to solving the following tasks:

- achievement of education excessiveness and advanced development of educational technologies in relation to the current professional point of reference for a specialist;

- self-actualization of the personality of a specialist;

- successful adaptation of teachers and management personnel to social dynamics and changes in education. tasks:

The system of further education should ensure the solution of the following strategic

- to ensure the introduction of educational programs focused on the formation of professional competencies;

- to ensure the creation of conditions for enhancement of existing and opening up of new specialties and professions in the system of primary, secondary and higher vocational education in consideration of changing needs of the labor market; 
- in terms of continuous education, to ensure formation of conditions that activate the innovative personal potential in educational activities;

- to create a system of comprehensive support for continuing professional education;

- to organize an active interface module of the professional navigation system in consideration of needs of the labor market.

On the basis of integration of federal and regional financial, intellectual, materialtechnological and information-telecommunication resources, creation of a unified information educational environment in the field of tourism, access to educational resources is opened, mobility of students increases, and distance education is receiving a new impetus.

High activity in the educational services market makes it possible to select for educational innovative programs (mobile education) that use modern technologies, forms and methods of teaching.

The main requirements for the content of further vocational education programs are:

- compliance with qualification requirements;

- continuity with the FSES;

- focus on innovative educational methods, technologies and teaching aids;

- compliance with program submission guidelines;

- compliance of the programs' content with their types.

At the same time, the problem of transition to a new model of higher education in the field of tourism is complicated by the need to coordinate a number of tasks.

At the interstate level - development and harmonization of models for compliance with national qualifications frameworks with meta-structures.

At the level of higher education institutions - comprehensive implementation of strategic and operational transformations of the educational process based on the resource approach.

At the level of structural units of universities (creative team) - creation and improvement of information and methodological support for transition to a competency model, including development of practice-oriented programs.

Practice-oriented programs will make it possible to objectively assess the results and progress of the educational process, as well as to form requirements for the educational process in accordance with demands of employers. Requirements for enhancement of training of tourism specialists, for optimizing the educational process predetermined the need to search for innovative forms and methods of teaching.

An innovative educational program of further vocational education should consist of three modules:

- theoretical training;

- practices in sectoral organizations;

- job training in leading organizations of the industry, including foreign ones.

The system of training of students in the further vocational education program can include three stages, presented in Figure 2: 


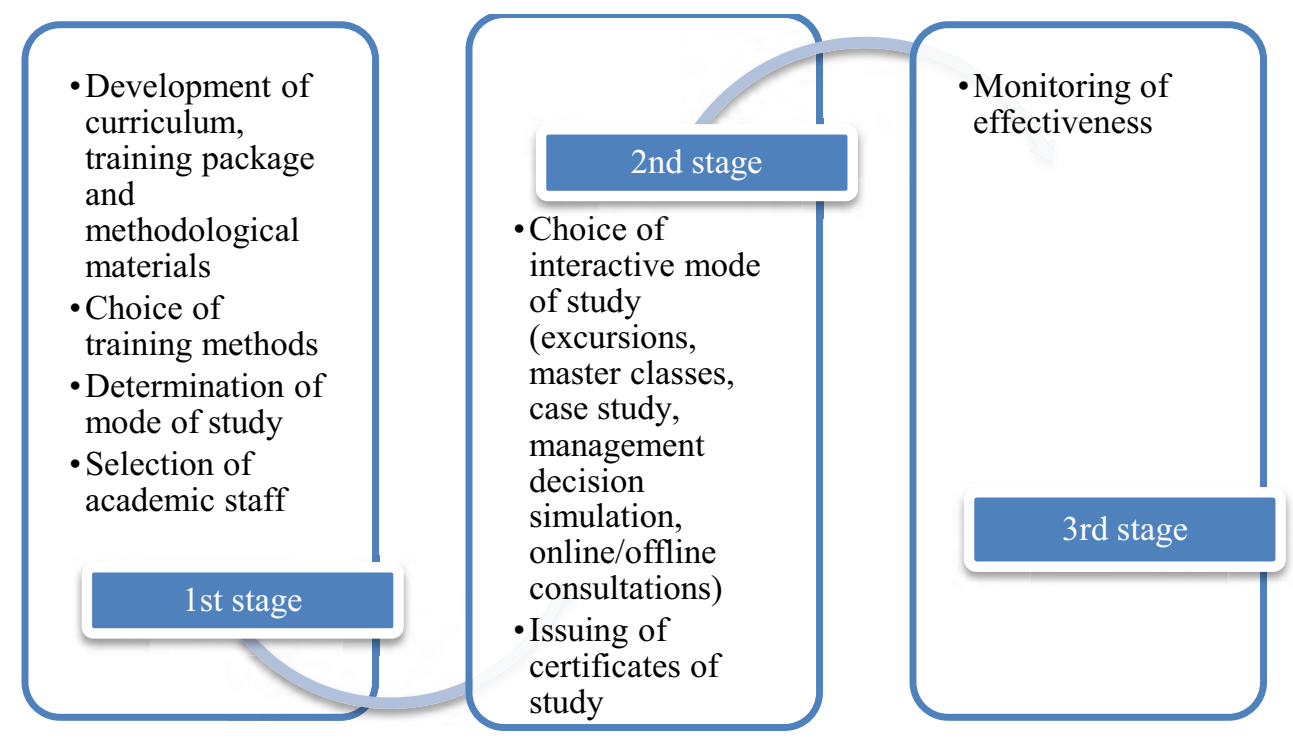

Fig. 2. System of training of learners for the further vocational education program

- preparation stage At this stage, training programs are developed and decisions are made on implementation of the program with consideration for the quality of the student body and needs of the customer;

- at the second stage, it is proposed to implement the educational program using modern educational technologies;

- the third stage - support of students after completing the educational program and providing consulting services.

In today's economic conditions, the system of further vocational education should provide continuous, high-quality and reasonable training, oriented both to the current needs of business entities and to future needs of the country's innovative development.

\section{Conclusions}

Following the conducted research a number of conclusions can be made. One of the main factors in development of further vocational education in the tourism and hospitality industry is innovation. The ability to perceive innovations and the choice of innovative development allow one to survive and develop in the context of growing dynamics of social changes and competition in the service market.

Within the conditions of informatization of the society, application of e-learning technologies in the system of further education becomes very relevant and promotes attraction of new target audiences. The use of e-learning technologies in the system of further education should not be limited to the use of distance courses; it is necessary to apply combined or hybrid learning, drawing together advanced features of new information technologies and providing remote access to educational materials in a traditional classroom.

In the course of development of programs for further vocational education, it is necessary to consider personal orientation of education, practical focus, mobility, multifunctionality, multilevel, variety of forms and methods of education, individualization of educational methods as a precondition for demand.

HR situation in the tourism and hospitality industry in Russia is characterized by the fact that young specialists have not gained enough experience to assume control, and 
experienced workers cannot professionally cover expanding demand and increasing tourist flow. In order to maintain personal competitiveness, a specialist should come back to the system of further vocational education from time to time in order to update his or her knowledge and acquire new skills.

A crucial criterion of the quality of tourist further education should be the presence of a system that ensures its compliance with changing needs of the industry and formation of personality in all of its aspects, i.e it should be supported by an educational structure that unites academic staff of a university and leading industry practitioners. It is the system of further vocational education that shall assume the role of an integrating link, which ensures interaction of organizations and enterprises of the real sector of the economy with the education system, in particular, in the field of development of professional standards, as well as in solving the problem of determining and correcting the content of professional educational programs in accordance with needs of employers.

\section{References}

1. A. M. Walder, Studies in Educational Evaluation, 54, 71-82 (2017) https://doi.org/10.1016/j.stueduc.2016.11.001

2. J. C.-C. Chow, C. Ren, B. Mathias, J. Liu, Children and Youth Services Review, 101, 217-224 (2019), https://doi.org/10.1016/j.childyouth.2019.04.008

3. M. Keinänen, J. Ursin, K. Nissinen, Studies in Educational Evaluation, 58, 30-36 (2018) https://doi.org/10.1016/j.stueduc.2018.05.007Get rights and content

4. V. Ellis, A. Childs, Teaching and Teacher Education, 77, 277-28 (2019) https://doi.org/10.1016/j.tate.2018.10.020Get rights and content

5. N. C. Jackson, Business Horizons, 62, 761-772 https://doi.org/10.1016/j.bushor.2019.08.002Get rights and content

6. S. Sh. Kazdanyan, Humanization of Education, 4, 27-34 (2016)

7. Z. Sh. Akbarova, Bulletin of the Bashkir University, 16, 1424-1428 (2011)

8. I. K. Voitovich, Bulletin of ISTU, 1(61), 159-162 (2014)

9. N. Nagibina, N. Ippolitova, General and Professional Education, 1, 36-44 (2012)

10. J. Qian, R. Law, X. Li, Journal of Hospitality, Leisure, Sport \& Tourism Education, 24, 120-129 (2019) https://doi.org/10.1016/j.jhlste.2019.02.003

11. H. J. Kim, M. Jeong, Tourism Management Perspectives, 25, 119-122 (2018) https://doi.org/10.1016/j.tmp.2017.11.025

12. A. D. Daniel, R. A. Costa, M. Pita, C. Costa, Journal of Hospitality and Tourism Management, 30, 65-72 (2017) https://doi.org/10.1016/j.jhtm.2017.01.002

13. V. N. Gioconda, M. Pasquale, D. Vecchio, Journal of Hospitality, Leisure, Sport \& Tourism Education, 25, 100175 (2019) https://doi.org/10.1016/j.jhlste.2018.10.003

14. J. Walker, V. N. Manyamba, Journal of Hospitality, Leisure, Sport \& Tourism Education, 26, 100213 (2020) https://doi.org/10.1016/j.jhlste.2019.100213Get rights and content

15. C. Behnke, S. Seo, K. Miller, Tourism Management, 42, 271-281 (2014) https://doi.org/10.1016/j.tourman.2013.12.010

16. Y. Belhassen, K. Caton, Tourism Management, 32, 1389-1396 (2011) https://doi.org/10.1016/j.tourman.2011.01.014

17. C. H. C. Hsu, Tourism Management Perspectives, 25, 181-183 (2018) https://doi.org/10.1016/j.tmp.2017.11.022 
18. M. Joppe, S. Elliot, Journal of Teaching in Travel and Tourism, 15, 201-203 (2015)

19. D. Eide, L. Fuglsang, J. Sundbo, Tourism Management, 63, 452-463 (2017) https://doi.org/10.1016/j.tourman.2017.06.029

20. S. Divisekera, V. K. Nguyen, Tourism Economics, 24, 998-1014 (2018)

21. B. Casais, J. Fernandes, M. Sarmento, Journal of Hospitality and Tourism Management, 42, 51-51 (2020) https://doi.org/10.1016/j.jhtm.2019.11.010

22. B. Pikkemaat, M. Peters, B. F. Bichler, Journal of Hospitality and Tourism Management, 41, 184-196 (2019) https://doi.org/10.1016/j.jhtm.2019.10.007

23. L. N. Kazmina, V. V. Provotorina, Humanities and Social and Economic Sciences, 1, 153-157 (2015)

24. L. N. Kazmina, V. V. Provotorina, Tourism and Hospitality Industry: Current Status and Development Potential, 122-126 (2016)

25. L. N. Kazmina, V. S. Makarenko, V. V. Provotorina, T. N. Grigorenko, International Journal of Economics and Business Administration, 7, 510-520 (2019) 